\title{
Factors Affecting Individual Attitudes and Perceptions towards Entrepreneurship: Does Education Really Matter?
}

\author{
Ozge Demiral ${ }^{1,2}$ \\ ${ }^{1}$ Department of Business Administration, Nigde University, Nigde, Turkey \\ ${ }^{2}$ Visiting Scholar, Department of Management and Organization, University of Southern California, Los Angeles, \\ California, USA \\ Correspondence: Ozge Demiral, 1030 South Wooster St., Apt. 5, Los Angeles, CA-90035, USA. Tel: \\ 1-213-332-7876.
}

Received: June 16, 2016

Accepted: June 24, 2016

Online Published: June 28, 2016

doi:10.5430/ijba.v7n4p43

URL: http://dx.doi.org/10.5430/ijba.v7n4p43

\begin{abstract}
Emphasizing the importance of new enterprises, studies have immensely attempted to explore what affect the entrepreneurship intentions of both potential and nascent entrepreneurs. In the literature, one of the factors with unclear effects on the entrepreneurship is the education that ambiguous results underline the necessity of distinguishing between educations. The purpose of this paper is to identify the factors affecting the attitudes and perceptions towards entrepreneurship with a special focus on the education classified as general and entrepreneurship education/training. The study uses a panel dataset of 11 European Union countries and over the period of 2007-2013, based on the Global Entrepreneurship Monitor's surveys pool. Findings reveal that the effects of the education indicators are still inconclusive and in general, individual attitudes and perceptions are more sensitive to the market-based aspects. Overall results support the premise that education in both general and entrepreneurial contexts is needed to be customized according to country-specific dynamics.
\end{abstract}

Keywords: attitudes, education, entrepreneurship, entrepreneurial conditions, perceptions

\section{Introduction}

Today, knowledge has dramatically replaced the physical capital and labor in not only business organizations but also in overall economies. Accordingly, beyond the given vocational capabilities, having the well-educated and creative individuals is seen as one of the most important factors in new knowledge creation and its sustainability for all countries, particularly in developed countries where knowledge-intensive activities generally dominate the most part of business operations. Moreover, as a way of boosting job opportunities, new and small firms have crucial contribution to economic dynamism. Therefore, entrepreneurship is widely accepted as one of the key pillars of market-oriented business life. Because of spillover effects of new business enterprises over every part of the societies, now, policymakers are endeavoring to foster overall entrepreneurial activities that also include rearranging education systems by adding new courses related to entrepreneurship (Lee et al., 2006; Dutta et al., 2011).

Entrepreneurship is a multifaceted concept affected by a wide array of micro- and macro-level factors. Macro factors are the consequences of interactions between political regulations, business environments, education system, logistics and infrastructure, financial developments, cultures, market structures, in brief by social, political and economic factors (Begley et al., 2005; Welter and Smallbone, 2011; Anderson et al., 2012; Audretsch, 2012). Micro factors center on the individual characteristics of leadership, creativeness, skills, capabilities, and attitudes towards entrepreneurship which can explain individually what makes people intended for setting a new business (Buli and Yesuf, 2015; Dutta et al., 2015).

The composite structure of the entrepreneurship also comes from its complex dynamisms that it has individual, firm-level and country-specific characteristics with mutual interactions (Busenitz et al., 2000; Veciana and Urbano, 2008). These factors also affect innovation, business sophistication and change readiness of societies that together determine the extent to which countries have pro-entrepreneurship business environments.

There is a global consensus that one of the key factors determining the entrepreneurial activities in a country is education. Entrepreneurship and education linkages comprise lifelong efforts that entrepreneurship education, 
directly or indirectly, starts at primary and secondary schools and continues in higher education such as vocational, college, business schools, etc. Besides these, formal training programs offered by the firms are also expected to improve their employees' skills for self-employment. All these bring a question of what the value added or returns of the education are, that is hard to answer. This difficulty is true for individuals and organizations or in a broad sense for the countries. There is a longstanding attempt among researchers from both business and economics to measure the entrepreneurship gains of the education. Compared to the strong evidence of economic growth and development benefits from education in the macro level, the results of individual and firm-level micro studies are not that clear and bring another question associating a linkage between the quality of education and the knowledge: Do formal education systems give explicit or tacit knowledge?

Explicit knowledge can be transferred easily by for example reading a text, listening to a conversation or observing the situation and environment. However, the crucial parts of knowledge are tacit which is hard to embed in people by the ways as in the explicit knowledge (Hausmann et al., 2011). Because the entrepreneurial process comprises purposive rational actions like preparing a business plan, evaluation of possible scenarios and market investigation, arranging the capital and human resources, costs and utility analysis and more, entrepreneurship has tacit knowledge origins beyond the simple definition that it is about bringing the resource together to produce goods and services. Therefore, being an entrepreneur requires a costly and time-consuming effort that education is an important instrument for it. Differences in education in transforming the tacit knowledge bring numerous disparities among the countries, even in entrepreneurial activities.

According to the fact that entrepreneurship has a wide range of meanings, there are many country-specific factors affecting the entrepreneurship. Studies seem to have focused on the determinants of the new business enterprises that are already set, or nascent business formations. They mostly investigate the effect of socio-economic factors, regulations, and institutions. Differently, this study deals with the pre-action period of the entrepreneurial activities investigating the determinants of the individual attitudes and perceptions towards entrepreneurship, focusing on the effects of education in 11 European Union countries (Belgium, Denmark, Finland, France, Hungary, Latvia, Portugal, Slovenia, Spain, Sweden, and the United Kingdom), that are well representatives of developed countries. In this context, besides the other multidimensional factors, this study examines how general or regular (somewhat compulsory in some nations) educations and entrepreneurship educations effect perceived capabilities and opportunities, and fear of failure perceptions together with entrepreneurial intentions of individuals from the 11 countries. In the rest of the study, we next present conceptual framework together with the different evidence in the related literature. Then, under the empirical framework, variables, dataset, model, and methodology are introduced, respectively. After results are presented, the study concludes with some policy implications and discussions.

\section{Conceptual Framework and Evidence}

\subsection{Determinants of Overall Entrepreneurship}

Numerous factors that affect all the entrepreneurship activities in a country can be grouped depending on economic, sociologic and demographic aspects that interact reciprocally. The economic factors center on the development stages of the countries. Starting from this, GEM (2016) presents the data of countries by their development stages following the World Economic Forum's (WEF) classification. According to WEF's classification, the countries in the factor-driven phases are dominated by commodity-based businesses, depending on natural resources and unskilled labor. In the efficiency-driven phase, countries are more competitive and more industrialized. Markets are dominated by capital-intensive large organizations that are getting benefits of economies of scale. The next progress is the innovation-driven stage where businesses become more knowledge-intensive, and the service sector expands. These differences in development paths are reflected in the entrepreneurship motivations that new startups tend to the centering on the services sector in innovation-driven developed countries, while manufacturing and agricultural sectors are dominant in efficiency-driven and factor-driven economies, respectively. In this context, key drivers for the resource-driven economies are institutions, infrastructure, business environment and human capital (education and health) indicators. For the efficiency-driven economies, key factors are higher education and training, market (goods, labor and financial) efficiencies, technological progress and market size while innovation-driven economies are characterized by business sophistication and innovation (Sala-i-Martin et al., 2014). As Porter's (1990) diamond model suggests, these stages and key factors determine the competitiveness of the nations. Adapting to our case, motivations and determinants of entrepreneurial activities in countries vary depending on which stage they are in. Therefore, economic factors can be extended including income level (strongly related to the development stages), unemployment rate, macroeconomic stability, and capital and labor market characteristics and income distributions. Those together explain the differences in entrepreneurial activities across countries as many studies confirm. 
Noorderhaven et al. (2004) found a negative and significant impact of per capita income on self-employment levels proxied by business ownership across 15 European countries for the period of 1978-2000. Using the nascent entrepreneurship data of global GEM-2002 for 36 countries, Wennekers et al. (2005) found evidence supporting the U-shaped relationship. Their results suggest that the level of economic development affect the nascent entrepreneurship.

Leading sociologic factors are institution-based ones. Institutions consist of composite interactions between traditions, beliefs, religions, values, norms and roles in a society and individuals socialize by learning these structural behaviors. Institutions have both formal and informal dynamics that effect entrepreneurship. When entrepreneurial activities, by definition, refer to the development of smaller firms and more narrowly success of firms that are introducing new products to the marketplace (innovation dimension) both organizational and country specific institutions are expected to affect the entrepreneurial activities. Besides the formal institutions like rules, law and regulations, as an informal structure culture has influences on the entrepreneurial activities as well.

Depending on of the data availability, studies seem to be restricted to the formal structures. However, formal and informal structures are naturally in strong interactions that lead to diversifications in personalities. In this context, using a large sample of 14,846 individuals, Beugelsdijk and Noorderhaven (2005) found that entrepreneurs differ from the general population and wage- and salary-earners. Entrepreneurs are more individually oriented than the rest of the population. Individual responsibility and effort are distinguishing characteristics. Supporting this evidence, a recent study of Lee-Ross (2015) compared the self-employed with waged and salaried workers and the general population in terms of entrepreneurial personality characteristics like the need for achievement, the locus of control, innovation, risk-taking and competitive aggression based on the World Values Survey dataset. The findings reveal that entrepreneurs are different in terms of their psychological characteristics. Moreover, some studies have started to examine the relationship between national measures of cognitive skill, including IQ tests and national entrepreneurial activities. For example, Jones and Hafer (2012) showed that higher national average of IQ reliably predicts entrepreneurship developments measured by various indicators in countries. These kinds of studies look at entrepreneurship from personal characteristics and combine innovation, creativeness, and entrepreneurship. In fact, the factors affecting the cognitive skills also have influences on the innovation, creativeness, and entrepreneurship. Within an organization job dissatisfaction or life dissatisfaction in a society, influence the choice of people to be either self-employed or waged-employee, as indicated by Noorderhaven et al. (2004). These specific cases highlight the importance of push and pull factors of entrepreneurship. One other important element is regulative legislation. Using a micro dataset of 37 developed and developing countries, Ardagna and Lusardi (2008) showed that regulation plays a critical role, particularly for those individuals who are to pursue the arising business opportunities. The individual characteristics affected by regulations are related to working status, social network, business skills, and attitudes towards risks.

The other aspects originate from demographics that also explain the entrepreneurship diversification within a country. Kauffman Index of Startup Activity (Fairlie et al., 2015) data reveals that there are considerable differences in startups by gender, race, nativity, age, veteran status and education level in the United States. Blanchflower et al. (2001) showed that for individuals the probability of preferring to be self-employed is strongly decreasing with age, while the probability of being self-employed is strongly increasing with age. Again, Ardagna and Lusardi's (2008) study confirmed that individual characteristics, such as gender, age, and status in the workforce are important determinants of entrepreneurship. Population growth is expected to have a positive effect on entrepreneurship since a growing population creates new and bigger consumer markets. Wennekers at al. (2005) for example found a positive effect of population growth on the rate of nascent entrepreneurship across 36 countries.

\subsection{Education-Entrepreneurship Nexus}

Personal entrepreneurial activities start with the perception of a niche or opportunity. After recognizing an opportunity, entrepreneurs organize resources and create a competitive advantage by being more innovative compared to other individuals. Societies embody institutional framework that somehow affect the individual entrepreneurship decisions (Schott and Sedaghat, 2014). One of these institutions is education by which societies are expected to motivate potential entrepreneurs, that is seen an important function of the national education systems.

Today's increasing globalization pattern requires organizations and countries to have well-educated employees who are capable of performing complex tasks and ready to the rapidly changing business environments together with the evolving needs. The other part of lifelong learning is staff training that is important for organizations to keep workers' skills updated (Sala-i-Martin et al., 2014). This is crucial parts within and inter-organization competitions that are in turn determine the overall competitiveness of the countries. 
After recognizing the fact that education does not only encourages the entrepreneurship but it can also effectively improve the innovation through knowledge and skills upgrading; countries have made education and training major content of their innovation strategies. Consistently, it is seen that countries those have replaced their traditional education system and methods by more innovation and research-development based ones, also have created more innovative business environments. These signs of progress are seen one of the catalysts driving the science, technology and innovation-based entrepreneurial activities in developed economies (Dutta et al., 2015).

The importance of education comes from its cumulative effects that it enhances personal capabilities of setting a business and meanwhile it creates entrepreneurship-led business culture through the spillovers of the individual skills. These externalities of education lead to increases in overall human capital in a country. When companies are encouraged for vocational training, these externalities create a more efficient business environment. Consequently, the skilled labor force is essential for companies and countries to enhance domestic and global competitiveness.

Education is seen an engine fostering the ability to innovate and to adopt new technologies. Schott and Sedaghat (2014) suggest that entrepreneurial activities are strongly associated with the national entrepreneurship education. Moreover, the quality of education directly contributes to the individuals' human capital and improving their creativeness and skills. They underline that entrepreneurs' formal education and their entrepreneurship training during schooling and upon graduation have positive effects on their innovation. Their findings support the evidence that besides the quantity, the quality of the national education system also matters for both human capital and entrepreneurship.

Against the theoretical expectations on the education and entrepreneurship nexus, the evidence in the related literature is ambiguous. Some studies (e.g. Reddy, 2011) found positive relationships, some other studies concluded with a negative relationship (e.g. Uhlaner and Thurik, 2004). In general, most part of studies indicates that the relationship depends on specific conditions (e.g. Neck and Greene, 2011).

Reddy's (2011) study, which specified business density as dependent variable while secondary and tertiary educations were regressed as independent variables, found evidence supporting the positive relationship between education and entrepreneurship in the case of African countries. However, Uhlaner and Thurik (2004) found that proportion of the population enrolled in secondary education together with income per capita is negatively associated with entrepreneurial activities in a sample of 28 countries from all around the world. With a skeptical approach Neck and Greene (2011), indicate that the answer to the question 'can entrepreneurship be taught' does not have a certain answer. The Authors emphasize that education systems need to go beyond the standard education methods and suggest practice-based entrepreneurship education. These include starting businesses as coursework, games and simulations, design-based thinking, and reflective practices. Variations in these concepts also explain the weak relations between regular educations and entrepreneurship across countries besides revealing the importance of the quality of the education rather than its quantity.

There are other challenges on the education, especially higher/college education that countries can fail in providing equal opportunities to all qualified students to access the education. Rising costs in higher education can also reduce the satisfaction with the education that expected real return or value-added of education can fall behind the expenses spent to access it. In terms of the satisfaction with the education, Table 1 shows various education-based indicators aggregated from the Executive Opinion Survey that World Economic Forum conducts globally (in 2014, over 13,000 executives in 144 economies were surveyed (WEF, 2016)). In Table 1, it is can be tracked that executives' opinions and quality evaluations vary over countries included in our sample. Overall scores reveal that there are not strong relations between enrollment rates and qualities as seen in the table 1. The executives from Finland are generally thinking the education quality is high in their countries.

Related to our case, these diversifications in the perceptions of educational qualities affect the decisions of the individuals to either set a new business or be a (high) waged-worker. Here, social norms are expected to play important roles that general attitudes of the society, based on the cultural and social norms, can affect the individual decisions. For example, if working for governmental organizations and public institutions or in a worldwide-known multinational are more appreciated or seen more prestigious by the societies, individuals can be discouraged for entrepreneurial activities even they are personally qualified and well equipped. When all these complex relations are considered, the linkages between education indicators and individual entrepreneurship attitudes and perceptions can be weak, or even paradoxical. 
Table 1. Higher education and training indicators of the sample countries, 2012-2014

\begin{tabular}{|c|c|c|c|c|c|c|c|c|c|c|}
\hline Belg. & Denm. & Finl. & France & Hung. & Latv. & Port. & Sloven. & Spain & Sweden & UK \\
\hline \multicolumn{11}{|c|}{ Secondary education enrollment, gross \% * } \\
\hline 107.3 & 124.7 & 107.7 & 109.7 & 101.6 & 97.7 & 112.9 & 4.2 & 130.8 & 98.4 & 95.4 \\
\hline$(15)$ & (4) & $(14)$ & $(11)$ & $(27)$ & $(43)$ & (8) & $(47)$ & (2) & $(40)$ & $(54)$ \\
\hline \multicolumn{11}{|c|}{ Tertiary education enrollment, gross \%* } \\
\hline 70.8 & 79.6 & 93.7 & 58.3 & 59.6 & 65.1 & 68.9 & 86.0 & 84.6 & 70.0 & 61.9 \\
\hline$(26)$ & $(14)$ & (4) & $(46)$ & $(44)$ & $(31)$ & $(29)$ & (7) & (8) & $(27)$ & $(36)$ \\
\hline \multicolumn{11}{|c|}{ Quality of the education system } \\
\hline 5.3 & 4.8 & 5.9 & 4.4 & 3.3 & 3.8 & 4.3 & 4.1 & 3.4 & 4.6 & 4.6 \\
\hline (6) & $(18)$ & (2) & $(34)$ & $(96)$ & $(65)$ & $(40)$ & $(48)$ & $(88)$ & (26) & $(23)$ \\
\hline \multicolumn{11}{|c|}{ Quality of math and science education } \\
\hline 6.0 & 4.5 & 6.3 & 5.2 & 4.3 & 4.9 & 4.5 & 5.2 & 3.9 & 4.4 & 4.3 \\
\hline (3) & (42) & (2) & (17) & (60) & $(27)$ & $(43)$ & (15) & (85) & (49) & (63) \\
\hline \multicolumn{11}{|c|}{ Quality of management schools } \\
\hline 6.0 & 5.2 & 5.6 & 5.7 & 4.3 & 4.6 & 5.9 & 4.4 & 5.9 & 5.2 & 5.8 \\
\hline (2) & (21) & $(12)$ & (8) & (66) & $(52)$ & (4) & (62) & (3) & (23) & (5) \\
\hline \multicolumn{11}{|c|}{ Internet access in schools } \\
\hline 5.9 & 6.0 & 6.5 & 4.7 & 5.4 & 6.0 & 5.7 & 6.0 & 4.8 & 6.3 & 6.3 \\
\hline (24) & (22) & (4) & (55) & (35) & $(21)$ & (28) & (20) & (51) & (8) & (7) \\
\hline \multicolumn{11}{|c|}{ Availability of research and training services } \\
\hline 6.0 & 5.3 & 5.9 & 5.3 & 3.9 & 4.4 & 5.1 & 4.4 & 4.7 & 5.4 & 5.7 \\
\hline (4) & $(18)$ & (6) & $(21)$ & $(85)$ & $(53)$ & $(24)$ & $(51)$ & $(35)$ & $(15)$ & (7) \\
\hline \multicolumn{11}{|c|}{ Extent of staff training } \\
\hline 5.1 & 4.9 & 5.3 & 4.5 & 3.6 & 4.4 & 4.2 & 3.7 & 3.7 & 5.1 & 4.7 \\
\hline (9) & (15) & (5) & (31) & (108) & (33) & $(54)$ & (98) & (96) & (10) & (23) \\
\hline
\end{tabular}

Notes: Indicators, except with asterisk (*), are derived from the World Economic Forum's Executive Opinion Survey. Scores are measured on a 1-to-7 scale ( 7 is the best score). The number in the parentheses denotes the rank of the country out of all 144 countries. Values greater than $100 \%$ in secondary education enrollment are due to the inclusion of over-aged and under-aged students because of early or late school entrance and grade repetition (WB WDI, 2016).

Source: WEF, Global Competitiveness Report 2014-2015 (Schwab, 2014)

\section{Variables, Data and Hypothesis Models}

Starting from the differences in entrepreneurial activities across countries, recently there is an increasing effort to identify what make some nations more entrepreneurial. The major challenge to do so is defining and measuring the entrepreneurial activities in a country or region (Fairlie et al., 2015) that especially the multi-country studies in the related literature severely suffer from. Meanwhile, there are noteworthy global efforts for filling the gap. The enterprise surveys (ES, 2016), for example, consider and collect a wide array of qualitative and quantitative data through face-to-face interviews with firm managers and owners regarding the business environment in their countries. The aspects of the data include infrastructure, trade, finance, regulations, taxes and business licensing, corruption, crime and informality, finance, innovation, labor, and perceptions about obstacles to doing business. Besides the currently operating enterprises, the doing business project (DB, 2016) provides measurements of business regulations for local small and medium-sized enterprises (SMEs) in a global context that are useful for both policymakers and 
researchers to examine the factors affecting both starting and operating a business. These standardized and harmonized data also allow researchers to compare countries in terms of entrepreneur-friendly business environment.

Related to the question why some countries are more entrepreneurial, the Global Entrepreneurship Monitor (GEM, 2016) also provides worldwide data within two major contexts: The entrepreneurial behavior and attitudes of individuals, and the national context called 'entrepreneurial framework conditions' that affect entrepreneurship. The GEM (2016) data also makes it possible to compare motivation and attitudes towards entrepreneurship capturing more information on perceived capabilities, perceived opportunities, fear of failure, entrepreneurial intentions, nascent entrepreneurship and more (see Bosma, 2013, for more about GEM data and its contribution to the entrepreneurship literature). According to the aim of the study, we use GEM data for the variables as summarized in Table 2. Moreover, in order to distinguish between general and entrepreneurship education, we get data on gross enrollment rates in both secondary and tertiary schools from the World Bank-World Development Indicators (WB WDI, 2016).

Table 2. Variables, definitions, and sources

\begin{tabular}{|c|c|c|}
\hline Variable & Definition & Source(s) \\
\hline \multicolumn{3}{|c|}{ Attitudes and perceptions: Dependent variables } \\
\hline$p c$ & Perceived capabilities (Specification-i ) & \multirow{4}{*}{$\begin{array}{l}\text { Adult Population } \\
\text { Surveys } \\
\text { (GEM, 2016) }\end{array}$} \\
\hline po & Perceived opportunities (Specification-ii ) & \\
\hline fof & Fear of failure rate (Specification-iii ) & \\
\hline$e i$ & Entrepreneurial intention (Specification-iv) & \\
\hline \multicolumn{3}{|c|}{ Entrepreneurial conditions: Explanatory variables } \\
\hline$f f e$ & Financing for entrepreneurs & \multirow{8}{*}{$\begin{array}{c}\text { National Expert } \\
\text { Surveys, } \\
\text { (GEM, 2016) }\end{array}$} \\
\hline$t b$ & Taxes and bureaucracy & \\
\hline $\operatorname{cinfr}$ & Commercial and professional infrastructure & \\
\hline open & Internal market openness & \\
\hline pinfr & Physical and services infrastructure & \\
\hline $\operatorname{csn}$ & Cultural and social norms & \\
\hline beet & Basic-school entrepreneurial education and training & \\
\hline peet & Post-school entrepreneurial education and training & \\
\hline gsed & General education, gross secondary school enrollment & \multirow[t]{2}{*}{ WB WDI, 2016} \\
\hline gted & General education, gross tertiary school enrollment & \\
\hline
\end{tabular}

\subsection{Attitudes and Perceptions towards Entrepreneurship}

The data of attitudes and perceptions towards entrepreneurship is those of the GEM's (2016) Adult Population Surveys that are globally administered to a representative national sample of at least 2000 respondents. According to the aim of this study, we have four dependent variables to be hypothesized and modeled individually.

i) Perceived capabilities (pc) variable is the percentage of the population aged 18-64 (individuals involved in any stage of entrepreneurial activity are excluded) who believe they have the required skills and knowledge to start a business. ii) Perceived opportunities (po) variable is the percentage of the population aged 18-64 (individuals involved in any stage of entrepreneurial activity are excluded) who see good opportunities to start a firm in the area where they live. iii) Fear of failure rate (fof) is the percentage of the population aged 18-64 (individuals involved in any stage of entrepreneurial activity are excluded) who indicate that fear of failure would prevent them from setting up a business. iv) The variable, entrepreneurial intentions (ei) is the percentage of the population aged 18-64 (individuals involved in any stage of entrepreneurial activity are excluded) who are latent entrepreneurs and who intend to start a business within three years. 


\subsection{Explanatory Variables: Key Determinants of the Entrepreneurship}

The independent variables are based on the GEM National Expert Surveys that monitor the factors believed to have significant effects on the entrepreneurship within the entrepreneurial framework conditions. The surveys are administered to a minimum of 36 carefully chosen experts in each country. They also take the entrepreneurship education and training into consideration. Besides, regular education data is obtained from the World Bank-World Development Indicators (WB WDI, 2016) which restricted the study to the period that ends in 2013 and a limited sample size, whereas GEM (2016) data is currently available for more than 50 countries until 2015.

i) Financing for entrepreneurs (ffe) measures the availability of financial resources, equity and debt (including grants and subsidies) for SMEs. ii) Taxes and bureaucracy ( $t b$ ) aspect consists of the taxes or regulations for they either encourage or discourage new startups and SMEs. Therefore, it shows the impacts of public policies at all levels of government, namely national, regional, and municipal. iii) Commercial and professional infrastructure (cinfr) is about the presence of property rights, commercial, accounting and other legal structures and it assesses the services and institutions that support or promote SMEs. iv) Internal market openness (open) gauges the extent to which new firms are free to enter existing markets. Therefore, it is able to capture the entry barriers that are important to the potential entrepreneurs. v) Physical and services infrastructure (pinfr) presents the ease of access to physical resources such as communication, utilities, transportation, land or space at a price that does not discriminate against SMEs. Again, this is crucial for SMEs in order to cope with competitiveness pressures in the market. vi) Cultural and social norms (csn) concern about the extent to which social and cultural norms encourage or allow actions leading to new business methods or activities that can potentially increase personal wealth and income. The social context of entrepreneurship is about how the larger social environment lends both cognitive and sociopolitical legitimacy to entrepreneurial activity (Hwang and Powell, 2005).

This so-called cultural indicator is able to capture the pro-entrepreneurship environment, which is strongly related to the economic conditions with respect to individual attitudes and perceptions towards the entrepreneurship.

The study specifically focuses on the effects of the education. Differently from related studies, we consider both general education and entrepreneurial education including training. This grouping allows us not only to compare explicit and tacit knowledge but also capture the reasons of the weak relations between education and entrepreneurship. In this context, last four variables are about the education and training. vii) Basic-school entrepreneurial education and training (beet) measure the extent of entrepreneurship education at basic school, i.e. primary and secondary schools. viii) Post-school entrepreneurial education and training (peet) identify the entrepreneurship education at post-secondary levels, i.e. higher education such as vocational, college, business schools, etc. ix). General secondary education (gsed) is the total enrollment in secondary education and measured as the percentage of the population of official secondary education age. $x$ ) General tertiary education (gted) is the total enrollment in tertiary education based on the international standard classification of education (ISCED) codes from 5 to 8 (WB WDI, 2016).

Multi-country studies in the related literature also control the relationships by development stage (income per capita), demographic factors (region, gender, age etc.). Because these characteristics are very similar among countries in our sample, we did not include these variables. It was also a technical necessity to limit the number of variables to 10 since we have 11 cross-section units in order to check the estimation for the random effect. Results can be strongly generalized to the European Union countries and partly to the developed countries.

\subsection{Hypotheses and Models}

In our theoretical model, individual attitudes and perceptions towards entrepreneurship are determined by entrepreneurial conditions. Therefore, our hypotheses are as follows:

H1: Attitudes and perceptions of perceived capabilities ( $p c$ ), perceived opportunities (po), fear of failure (fof) and entrepreneurial intention (ei) towards entrepreneurship are affected by entrepreneurial conditions consisting of financing (ffe), taxes and bureaucracy (tb), commercial infrastructure (cinf), market openness (open), physical infrastructure (pinfr), and cultural and social norms (csn).

H2: The effects of general education and entrepreneurship education on the attitudes and perceptions differ that entrepreneurship education and training are expected to have positive effects while general educations are expected to be neutral even have a negative effect on the attitudes and perceptions towards entrepreneurship.

Consistently, the hypotheses are modeled by four regression specifications as shown in the equation 1. 


$$
\begin{gathered}
\text { i) } \ln (\text { pc })_{i t}=\alpha_{1}+\beta_{1} \ln (\text { ffe })_{i t}+\beta_{2} \ln (\text { tb })_{i t}+\beta_{3} \ln (\text { cinfr })_{i t}+\beta_{4} \ln (\text { open })_{i t}+\beta_{5} \ln (\text { pinfr })_{i t} \\
+\beta_{6} \ln (\text { csn })_{i t}+\beta_{7} \ln (\text { beet })_{i t}+\beta_{8} \ln (\text { peet })_{i t}+\beta_{9} \ln (\text { gsed })_{i t}+\beta_{10} \ln (\text { gted })_{i t}+e_{i t} \\
\text { ii) } \ln (\text { po })_{i t}=\alpha_{2}+\partial_{1} \ln (\text { ffe })_{i t}+\partial_{2} \ln (\text { tb })_{i t}+\partial_{3} \ln (\text { cinfr })_{i t}+\partial_{4} \ln (\text { open })_{i t}+\partial_{5} \ln (\text { pinfr })_{i t} \\
+\partial_{6} \ln (\text { csn })_{i t}+\partial_{7} \ln (\text { beet })_{i t}+\partial_{8} \ln (\text { peet })_{i t}+\partial_{9} \ln (\text { gsed })_{i t}+\partial_{10} \ln (\text { gted })_{i t}+u_{i t} \\
\text { iii }) \ln (\text { fof })_{i t}=\alpha_{3}+\phi_{1} \ln (\text { ffe })_{i t}+\phi_{2} \ln (\text { tb })_{i t}+\phi_{3} \ln (\text { cinfr })_{i t}+\phi_{4} \ln (\text { open })_{i t}+\phi_{5} \ln (\text { pinfr })_{i t} \\
+\phi_{6} \ln (\text { csn })_{i t}+\phi_{7} \ln (\text { beet })_{i t}+\phi_{8} \ln (\text { peet })_{i t}+\phi_{9} \ln (\text { gsed })_{i t}+\phi_{10} \ln (\text { gted })_{i t}+\varepsilon_{i t} \\
\text { iv) } \ln (\text { ei })_{i t}=\alpha_{4}+\theta_{1} \ln (\text { ffe })_{i t}+\theta_{2} \ln (\text { tb })_{i t}+\theta_{3} \ln (\text { cinfr })_{i t}+\theta_{4} \ln (\text { open })_{i t}+\theta_{5} \ln (\text { pinfr })_{i t} \\
+\theta_{6} \ln (\text { csn })_{i t}+\theta_{7} \ln (\text { beet })_{i t}+\theta_{8} \ln (\text { peet })_{i t}+\theta_{9} \ln (\text { gsed })_{i t}+\theta_{10} \ln (\text { gted })_{i t}+\omega_{i t} \\
(i=1, \ldots, 11 ; \quad t=2007, \ldots, 2013)
\end{gathered}
$$

In equation 1, all the variables are the same as previously defined in Table 2 and $i$ and $t$ stand for the cross section units (countries) and temporal units (years), respectively, while $\alpha_{1}, \ldots, \alpha_{4}$ are country-specific intercepts. The composite error terms, $e_{i t}, u_{i t}, \varepsilon_{i t}, \omega_{i t}$, comprise cross-sectional and temporal influences of all other factors not included in the model. Finally, all $\beta_{i}, \partial_{i}, \phi_{i}$, and $\theta_{i}(i=1, \ldots, 10)$ are the parameters to be estimated. All variables are transformed into the natural logarithmic forms for boosting linearity, multivariate normality, and homoscedasticity assumptions.

\section{Analysis and Results}

The study uses a dataset of 11 European Union (EU) countries for a 7-year period spanning from 2007 to 2013. Because of several missing values, we have a slightly unbalanced panel dataset. When considered a large number of individuals surveyed in each year and country, this unbalanced structure is not a serious problem. Additionally, statistical program we use (Stata) efficiently adjust the missing values.

In order to robust the regression estimation and have efficient coefficients; first, we checked each series for

\begin{tabular}{|c|c|c|c|c|c|c|c|c|c|c|c|c|c|c|}
\hline & $p c$ & po & $f o f$ & $e i$ & $f f e$ & $t b$ & beet & peet & gsed & gted & $\operatorname{cinfr}$ & open & pinfr & $c s n$ \\
\hline Mean & 3.75 & 3.34 & 3.55 & 2.17 & .94 & .89 & .73 & 1.01 & 4.69 & 4.27 & 1.14 & .96 & 1.37 & .93 \\
\hline Median & 3.77 & 3.44 & 3.59 & 2.17 & .94 & .91 & .77 & 1.02 & 4.67 & 4.25 & 1.15 & .96 & 1.37 & .94 \\
\hline Max. & 4.03 & 4.26 & 3.85 & 3.21 & 1.31 & 1.19 & 1.07 & 1.20 & 5.10 & 4.55 & 1.32 & 1.21 & 1.49 & 1.16 \\
\hline Min. & 3.43 & 1.04 & 3.14 & .95 & .58 & .43 & .31 & .79 & 4.55 & 4.02 & .92 & .65 & 1.23 & .63 \\
\hline Std. Dev. & .15 & .59 & .17 & .49 & .13 & .19 & .18 & .10 & .10 & .16 & .08 & .11 & .06 & .13 \\
\hline Skewness & -.28 & -.89 & -.28 & .05 & .09 & -.25 & -.27 & -.38 & 1.23 & .21 & -.32 & -.13 & -.37 & -.02 \\
\hline Kurtosis & 1.90 & 5.24 & 2.24 & 2.60 & 3.30 & 2.23 & 2.26 & 2.62 & 5.13 & 1.78 & 3.08 & 2.65 & 2.59 & 2.07 \\
\hline $\mathrm{J}-\mathrm{B}$ & 3.51 & 18.95 & 2.02 & .38 & .28 & 1.94 & 1.92 & 1.72 & 24.30 & 3.79 & 1.00 & .44 & 1.64 & 1.95 \\
\hline $\mathrm{J}-\mathrm{B}(p)$ & .17 & .00 & .36 & .82 & .86 & .37 & .38 & .42 & .00 & .14 & .60 & .80 & .44 & .37 \\
\hline$p c$ & 1 & & & & & & & & & & & & & \\
\hline po & $-.35^{*}$ & 1 & & & & & & & & & & & & \\
\hline$f o f$ & -.11 & -.14 & 1 & & & & & & & & & & & \\
\hline$e i$ & .19 & $-.25^{*}$ & $.24 *$ & 1 & & & & & & & & & & \\
\hline
\end{tabular}
normality through kurtosis and skewness values together with the Jarque-Bera (J-B) test. As seen in Table 3, J-B statistic indicates the series, except $\ln ($ po $)$ and $\ln$ (gsed), are normally distributed. For the desired normal distribution, the values of skewness and kurtosis are required to be zero that refers to a perfect symmetry. However, in the literature, there are different thresholds used. In a loose approach, values greater than 2 and 7 for skewness and kurtosis respectively, are considered distorting the normality seriously (Stevens, 2009). In our sample, the skewness values are ranging between -0.02 and 1.23 while kurtosis values differ between 1.78 and 5.24 that mean there are no crucial deviations from the normality. The histograms of the series also seemingly support the normality.

Table 3. Descriptive statistics and correlation matrix 


\begin{tabular}{|c|c|c|c|c|c|c|c|c|c|c|c|c|c|c|}
\hline$f f e$ & $-.36^{*}$ & $.34 *$ & $-.32 *$ & $-.28 *$ & 1 & & & & & & & & & \\
\hline$t b$ & $-.44^{*}$ & $.58 *$ & -.08 & $-.39 *$ & $.40^{*}$ & 1 & & & & & & & & \\
\hline beet & $-.22 *$ & $.53 *$ & $-.24 *$ & -.14 & $.46^{*}$ & $.50 *$ & 1 & & & & & & & \\
\hline peet & -.08 & -.09 & -.06 & $.26^{*}$ & $.41^{*}$ & .05 & $.29 *$ & 1 & & & & & & \\
\hline gsed & $-.23 *$ & -.01 & $.45^{*}$ & $-.28^{*}$ & -.16 & .07 & $-.24 *$ & $-.28 *$ & 1 & & & & & \\
\hline gted & .11 & $.23^{*}$ & $-.41 *$ & $-.30 *$ & -.07 & $.22 *$ & $.28^{*}$ & -.18 & .08 & 1 & & & & \\
\hline cinfr & $-.33^{*}$ & .18 & -.06 & -.10 & $.62 *$ & $.47^{*}$ & $.65 *$ & $.50 *$ & -.18 & -.06 & 1 & & & \\
\hline open & -.22 & $.26^{*}$ & -.14 & $-.38 *$ & $.53 *$ & $.51^{*}$ & $.67 *$ & .13 & -.13 & .04 & $.72 *$ & 1 & & \\
\hline pinfr & $-.42 *$ & $.39^{*}$ & $-.27^{*}$ & -.03 & $.49 *$ & $.47^{*}$ & $.44 *$ & .10 & -.05 & .17 & $.41^{*}$ & $.33^{*}$ & 1 & \\
\hline$c s n$ & $-.25 *$ & $.50 *$ & .06 & -.21 & $.27 *$ & $.62^{*}$ & $.69 *$ & .05 & -.07 & -.07 & $.54 *$ & $.67 *$ & $.34^{*}$ & 1 \\
\hline
\end{tabular}

Notes: All variables are in the natural logarithmic forms. ${ }^{*}$ Correlation coefficients are statistically significant $(\mathrm{p}<.10)$

Within a panel framework, least square estimation can be conducted through pooled, fixed effect and random effect regression models with various tests to determine the best-fitting model (Wooldridge, 2002). The redundant fixed effects tests (the $F$-test) compare fixed effect to pooled regressions. The null hypothesis indicates country-specific effects are the same while alternative hypothesis implies these effects differ between at least two countries. We found $F$-test values affirming pooled regression is not appropriate for all model specifications at $10 \%$ level. On comparing fixed and random effects, Hausman test is commonly used. Hausman test statistics are found verifying fixed effect models are the most appropriate method to estimate all models at $5 \%$ level. Consequently, we estimate the models for cross-section fixed effects.

While checking for robustness, Durbin-Watson (D-W) statistics and residual cross-section dependence test statistics revealed no autocorrelation and heteroscedasticity, respectively. The last control was about the multicollinearity problem that refers to a situation in which two or more explanatory variables are highly and linearly related. Multicollinearity can be identified by checking the variance inflation factors (Klein and Rai, 2009; Peng and Lai, 2012). The variance inflation factors (VIFs) infer whether a predictor has a strong linear relationship with the other predictor(s). There are not certain criteria for the VIF that some studies suggest that a value of 10 is a value at which to worry (Field, 2009, 223-224). However, some studies suggest that values above 3.3 are worthy of concern about multicollinearity (Peng ve Lai, 2012). Even we expected multicollinearity since we have a wide array of related explanatory variables; we had VIF values ranging between 0.14 and 2.2 that confirm no serious multicollinearity. Finally, the results of fixed-effect panel least square estimation are reported in Table 4.

Table 4. Factors affecting individual attitudes and perceptions towards entrepreneurship

\begin{tabular}{lcccc}
\hline Variables & $\begin{array}{c}\text { Specification-i } \\
\text { dependent variable: } \\
\ln (\mathrm{pc})\end{array}$ & $\begin{array}{c}\text { Specification-ii } \\
\text { dependent variable: } \\
\ln (\text { po })\end{array}$ & $\begin{array}{c}\text { Specification-iii } \\
\text { dependent variable: } \\
\ln (f \circ f)\end{array}$ & $\begin{array}{c}\text { Specification-iv } \\
\text { dependent variable: } \\
\ln (\text { ei })\end{array}$ \\
\hline $\ln (f f e)$ & $.115[1.073]$ & $2.135[1.999]^{*}$ & $-.200[-.734]$ & $-.316[-.512]$ \\
\hline $\ln ($ tb) & $-.144[-1.957]^{*}$ & $.268[.375]$ & $.220[.909]$ & $.806[2.086]^{* *}$ \\
\hline $\ln ($ cinfr $)$ & $.298[2.237]^{* *}$ & $.044[.040]$ & $.486[2.496]^{* *}$ & $-.337[-.757]$ \\
\hline $\ln ($ open $)$ & $-.316[-3.948]^{* * *}$ & $-1.140[-1.170]$ & $.179[.969]$ & $-1.942[-2.822]^{* * *}$ \\
\hline $\ln ($ pinfr $)$ & $.239[1.240]$ & $-3.881[-3.437]^{* * *}$ & $-.77[-3.323]^{* * *}$ & $2.054[3.591]^{* * *}$ \\
\hline $\ln ($ csn $)$ & $.098[.709]$ & $2.278[5.948]^{* * *}$ & $.033[.070]$ & $-.094[-.168]$ \\
\hline $\ln ($ beet $)$ & $-.152[-.971]$ & $-.707[-.908]$ & $-.082[-.218]$ & $.792[1.450]$ \\
\hline $\ln ($ peet $)$ & $.054[.346]$ & $.021[.033]$ & $.247[.932]$ & $-.877[-1.969]^{*}$ \\
\hline
\end{tabular}




\begin{tabular}{ccccc}
\hline $\ln ($ gsed $)$ & $-.185[-4.100]^{* * *}$ & $.795[1.333]$ & $.772[3.983]^{* * *}$ & $.187[.846]$ \\
\hline $\ln ($ gted $)$ & $.312[1.631]$ & $2.142[1.850]^{*}$ & $.004[.008]$ & $.862[1.334]$ \\
\hline Constant & $2.909[3.081]^{* * *}$ & $-7.028[-1.331]$ & $.017[.007]$ & $-2.989[-.831]$ \\
\hline $\mathrm{R}^{2}$ & .909 & .769 & .722 & .818 \\
\hline F-stat. & $17.037(.000)^{* * *}$ & $5.664(.000)^{* * *}$ & $4.413(.000)^{* * *}$ & $7.657(.000)^{* * *}$ \\
\hline D-W stat. & 2.078 & 2.357 & 2.201 & 1.962 \\
\hline F-test & $18.764(.000)^{* * *}$ & $2.054(.058)^{*}$ & $2.169(.045)^{* *}$ & $5.232(.000)^{* * *}$ \\
\hline $\begin{array}{c}\text { Hausman } \\
\text { test }\end{array}$ & $187.644(.000)^{* * *}$ & $2.539(.025)^{* *}$ & $21.691(.017)^{* *}$ & $52.323(.000)^{* * *}$ \\
\hline
\end{tabular}

Notes: ${ }^{* * *} \mathrm{p}<.01 ; * * .01<\mathrm{p}<.05 ; * .05<\mathrm{p}<.10$. Probabilities are in the parentheses and $\mathrm{t}$-statistics are in the brackets.

Estimated significant coefficients in Table 4 show that perceived capabilities $(p c)$ are negatively associated with taxes and bureaucracy $(t b)$, internal market openness (open) and general secondary education (gsed) while commercial and professional infrastructure ( $\operatorname{cinfr}$ ) have a contribution to the capability perception. Entrepreneurial education and training at both basic-school (beet) and post-school level (peet) do not have any significant influence. For the perceived opportunities ( $p o$ ), financing for entrepreneurs (ffe), cultural and social norms (csn) and general tertiary education (gted) have positive effects. However, physical and services infrastructures (pinfr) have negative impact. Fear of failure rate $(f \circ f)$ has negatively associated with the physical and services infrastructure (pinfr). Commercial and professional infrastructures (cinfr) along with the general secondary education ( $g s e d$ ) are found leading to increases in the fear of the failure. Finally, taxes and bureaucracy $(t b)$ and physical and services infrastructure (pinfr) are found stimulating the entrepreneurial intentions (ei), while internal market openness (open) and the post-school entrepreneurial education and training (peet) reduce the entrepreneurial intention. The ambiguous results, that imply a weak support for the hypotheses, revisit the debate about the return of the education and keep the doors open to the discussions about the relationships between education, training and entrepreneurship in case of 11 developed countries sampled in the study.

\section{Conclusion}

Starting from the worldwide consensus about the important functions of entrepreneurship to create an inclusive business life, studies have immensely attempted to clarify the determinants of the entrepreneurship intentions of both potential and nascent entrepreneurs. In the literature, one of the factors with unclear effects on the entrepreneurial activities is the education that ambiguous results underline the necessity of distinguishing between educations levels. This paper purposed to identify the factors affecting the individual attitudes and perceptions towards entrepreneurship with a special focus on the education classified as general and entrepreneurship education/training. We used a panel dataset of 11 European Union countries sampled as a proxy of the developed countries for the period of 2007-2013 from the Global Entrepreneurship Monitor's surveys pool and tested the hypotheses modeled by four equations where the dependent variables are perceived capabilities, perceived opportunities, fear of failure and entrepreneurial intentions towards entrepreneurship.

The results from the fixed-affect panel least square estimations indicate that the effects of entrepreneurial conditions and education vary across individual attitudes and perceptions. Perceived capabilities are negatively associated with taxes and bureaucracy, internal market openness and general secondary education while positively affected by commercial and professional infrastructure. Entrepreneurial education and training at both basic-school and post-school levels, do not have any significant influence on perceived entrepreneurship capabilities. For the perceived opportunities; financing for entrepreneurs, cultural and social norms and general tertiary education have positive effects. The finding of physical and services infrastructures have negative impact, indicates the competitiveness pressures that physical and services infrastructures 'for everyone' can hinder individuals to start a business. This can come from the difficulties to perceive the opportunities earlier than those who can also recognize these occasions.

Fear of failure is negatively associated with the physical and services infrastructures. The positive relationship between commercial and professional infrastructures and fear of failure again indicates the competition based-discourage effects. The finding that the general secondary education is leading to increases in the fear of the failure may be explained by the lacks of entrepreneurship education at this level. When this is considered together with the insignificant effects of the upper level education, new courses consisting of simulations on starting 
businesses, strategic management, negotiations and crises management are expected to encourage potential entrepreneurs, as some studies have already indicated. Finally, taxes and bureaucracy, and physical and services infrastructure are found stimulating the entrepreneurial intentions as expected. However, internal market openness and the post-school entrepreneurial education and training reduce the entrepreneurial intentions. Again, internal market openness indicates more competition pressures while the negative effect of the post-school entrepreneurial education and training seems to raise the queries on the entrepreneurship return and the quality of education and training together with different motivations from the education.

Findings reveal that the effects of the education indicators are still ambiguous and in general, individual attitudes and perceptions are more sensitive to the market-based aspects. In this context, reducing the regulations, implementing policies intended for elimination the discouraging effects of the competition pressures that market openness tends to bring, seem to contribute to make the long-run projections for potential entrepreneurs.

Overall results on the effect of education have two implications. First, the findings support the premise that education in both general and entrepreneurial contexts is needed to be capability-oriented and customized according to country-specific, and in a narrow sense individual dynamics, taking all the external factors into consideration. Secondly, the results provoke the debate about the education-training-entrepreneurship nexus and keep the doors open to the argument whether entrepreneurs are born or made. These debates encourage researchers to investigate individual characteristics like psychological factors and personalities rather than environmental factors. In a holistic approach, we suggest future studies to include more variables that are mixed of both macro- and micro perspectives. Moreover, the effects of the education are needed to be investigated considering the contents of education and its methods.

\section{References}

Anderson, A. R., Dodd, S. D., \& Jack, S. L. (2012). Entrepreneurship as connecting: Some implications for theorising and practice. Management Decision, 50(5), 958-971. http://dx.doi.org/10.1108/00251741211227708

Ardagna, S., \& Lusardi, A. (2008). Explaining international differences in entrepreneurship: The role of individual characteristics and regulatory constraints. NBER Working Papers, 14012. http://dx.doi.org/10.3386/w14012

Audretsch, D. (2012). Entrepreneurship research. Management Decision, 50(5), 755-764. http://dx.doi.org/10.1108/00251741211227384

Begley, T., Tan, W. L., \& Schoch, H. (2005). Politico-economic factors associated with interest in starting a business: A multi-country study. Entrepreneurship Theory \& Practice, 29(1), 35-55. http://dx.doi.org/10.1111/j.1540-6520.2005.00068.x

Beugelsdijk, S., \& Noorderhaven, N. (2005). Personality characteristics of self-employed: An empirical study. Small Business Economics, 24(2), 159-167. http://dx.doi.org/10.1007/s11187-003-3806-3

Blanchflower, D. G., Oswald, A., \& Stutzer, A. (2001). Latent entrepreneurship across nations. European Economic Review, 45(4-6), 680-691. http://dx.doi.org/10.1016/S0014-2921(01)00137-4

Bosma, N. (2013). The Global Entrepreneurship Monitor (GEM) and its impact on entrepreneurship research. Foundations and Trends in Entrepreneurship, 9(2), 143-248. http://dx.doi.org/10.1561/0300000033

Buli, B. M., \& Yesuf, W. M. (2015). Determinants of entrepreneurial intentions: Technical-vocational education and training students in Ethiopia. Education + Training, 57(8/9), 891-907. http://dx.doi.org/10.1108/ET-10-2014-0129

Busenitz, L. W., Gómez, C., \& Spencer, J. W. (2000). Country institutional profiles: Unlocking entrepreneurial phenomena. The Academy of Management Journal, 43(5), 994-1003. Retrieved from http://www.jstor.org/stable/1556423

DB-Doing Business. (2016). Retrieved from http://www.doingbusiness.org/

Dutta, D. K., Li, J., \& Merenda, M. (2011). Fostering entrepreneurship: Impact of specialization and diversity in education. International Entrepreneurship and Management Journal, 7(2), 163-179. http://dx.doi.org/10.1007/s11365-010-0151-2

Dutta, S., Lanvin, B., \& Wunsch-Vincent, S. (2015). The Global Innovation Index 2015: Effective innovation policies for development. (Eds.), Fontainebleau, Ithaca, and Geneva: Cornell University, INSEAD, and WIPO.

ES-Enterprise Surveys. (2016). Retrieved from http://www.enterprisesurveys.org/

Fairlie, R. W., Morelix, A., Reedy, E. J., \& Russell, J. (2015). 2015 Kauffman index of startup activity: National trends. Kansas City: The Ewing Marion Kauffman Foundation. 
Field, A. (2009). Discovering statistics using SPSS (3rd. ed.). Thousand Oaks: SAGE Publications.

GEM-Global Entrepreneurship Monitor. (2016). Retrieved from http://www.gemconsortium.org/

Hausmann, R., Hidalgo, C. A., Bustos, S., Coscia, M., Chung, S., Jimenez, J., ... Yildirim, M. A. (2011). The atlas of economic complexity: Mapping paths to prosperity (2nd. ed.). Cambridge: MIT Press.

Hwang, H., \& Powell, W. W. (2005). Institutions and entrepreneurship. Alvarez, S. A., Agarwal, R., and Sorenson, O. (Eds.). Handbook of entrepreneurship research, 201-232, http://dx.doi.org/10.1007/0-387-23622-8_10

Jones, G., \& Hafer, R. W. (2012). IQ and entrepreneurship: International evidence. GMU Working Paper in Economics, 12-19, http://dx.doi.org/10.2139/ssrn.2057396

Klein, R., \& Rai, A. (2009). Interfirm strategic information flows in logistics supply chain relationships. MIS Quarterly, 33(4), 735-762.

Lee, S. M., Lim, S. B., Pathak, R. D., Chang, D., \& Li, W. (2006). Influences on students attitudes toward entrepreneurship: A multi-country study. The International Entrepreneurship and Management Journal, 2(3), 351-366. http://dx.doi.org/10.1007/s11365-006-0003-2

Lee-Ross, D. (2015). Personality characteristics of the self-employed: A comparison using the world values survey data set. Journal of Management Development, 34(9), 1094-1111. http://dx.doi.org/10.1108/JMD-06-2014-0062

Neck, H. M., \& Greene, P. G. (2011). Entrepreneurship education: Known worlds and new frontiers. Journal of Small Business Management, 49(1), 55-70. http://dx.doi.org/10.1111/j.1540-627X.2010.00314.x

Noorderhaven, N., Thurik, R., Wennekers, S., \& Stel, A. (2004). The role of dissatisfaction and per capita income in explaining self-employment across 15 European countries. Entrepreneurship Theory and Practice, 28(5), 447-466. http://dx.doi.org/10.1111/j.1540-6520.2004.00057.x

Peng, D. X., \& Lai, F. (2012). Using partial least squares in operations management research: A practical guideline and summary of past research. Journal of Operations Management, 30(2012), 467-480. http://dx.doi.org/10.1016/j.jom.2012.06.002

Porter, M. (1990). The competitive advantage of nations. New York: The Free Press.

Reddy, C. D. (2011). Exploring the link between education and entrepreneurship. In Hewitt, L. L. M. (Ed.), Entrepreneurship, training, education and job creation. Westdene, Bloemfontein: SUN MeDIA, 101-114.

Sala-i-Martin, X., Bilbao-Osorio, B., Battista, A. D., Hanouz, M. D., Galvan, C., \& Geiger, T. (2014). The global competitiveness index 2014-2015: Accelerating a robust recovery to create productive jobs and support inclusive growth. In Schwab, K. (Ed.). The Global Competitiveness Report 2014-2015. Geneva: WEF, 3-51.

Schott, T., \& Sedaghat, M. (2014). Entrepreneurs' innovation embedded in networks and national education. Small Business Economics, 43(2), 463-476. http://dx.doi.org/10.1007/s11187-014-9546-8

Schwab, K. (2014). The global competitiveness report 2014-2015: Insight report. (Ed.), Geneva: WEF.

Stevens, J. P. (2009). Applied multivariate statistics for the social sciences (5th ed.). New York: Routledge, Taylor \& Francis Group.

Uhlaner, L. M., \& Thurik, A. R. (2004). Post-materialism: A cultural factor influencing total entrepreneurial activity across nations. Max Planck Institute Discussion Papers on Entrepreneurship, Growth and Public Policy. Retrieved from ftp://papers.econ.mpg.de/egp/discussionpapers/2004-07.pdf

Veciana, J. M., \& Urbano, D. (2008). The institutional approach to entrepreneurship research: Introduction. International Entrepreneurship and Management Journal, 4(4), 365-379. http://dx.doi.org/10.1007/s11365-008-0081-4

WB WDI-World Bank World Development Indicators. (2016). Retrieved from http://data.worldbank.org/data-catalog/world-development-indicators

WEF-World Economic Forum. (2016). Retrieved from http://www.weforum.org/

Welter, F., \& Smallbone, D. (2011). Institutional perspectives on entrepreneurial behaviour in challenging environments. Journal of Small Business Management, 49(1). http://dx.doi.org/107-125.10.1111/j.1540-627X.2010.00317.x

Wennekers, S., Stel, A., Thurik, R., \& Reynolds, P. (2005). Nascent entrepreneurship and the level of economic development. Small Business Economics, 24(3), 293-309. http://dx.doi.org/10.1007/s11187-005-1994-8

Wooldridge, J. M. (2002). Econometric analysis of cross-section and panel data. Cambridge: MIT Press. 